\title{
Transnational Human Rights Obligations
}

\author{
Sigrun I. Skogly* \& Mark Gibney**
}

\section{INTRODUCTION}

In the Trail Smelter case, United States vs. Canada, the Court held that:

Under the principles of international law ... no State has the right to use or permit the use of its territory in such a manner as to cause injury by fumes in or to the territory of another or the properties or persons therein, when the case is of serious consequence and the injury is established by clear and convincing evidence. ${ }^{1}$

This case was heard close to a century ago, yet little has developed in terms of states' obligations or responsibility for transnational effects of their actions. This is true for international law generally, and for international human rights law more specifically.

The topic of transnational human rights obligations for states has not been widely explored. ${ }^{2}$ By transnational obligations, we imply the possibility that states may have obligations relating to the human rights effects of their external activities, such as trade, development cooperation, participation in international organizations, and security activities. Most work of human

* Sigrun I. Skogly is Lecturer of Law at Lancaster University, United Kingdom. She holds an LL.M. from Essex University, and a Ph.D. in Law from University of Oslo. Her work in recent years has focused on human rights obligations, in particularly non-state actors. She is the author of the book The Human Rights Obligations of the World Bank and the International Monetary Fund. She is currently working on a book project on states' human rights obligations in foreign affairs.

** Mark Gibney is the Belk Distinguished Professor at the University of North CarolinaAsheville.

An earlier version of this article was presented at the International Studies Association's Annual meeting in Chicago, Illinois, Feb. 2001.

1. Trail Smelter Case (United States v. Canada), 3 R.I.A.A. 1905 (1941). See also Mark Gibney, Katarina Tomasěvski, \& Jens Vedsted-Hansen, Transnational State Responsibility for Violations of Human Rights, 12 Harvard Hum. Rts. J. 273 (1999).

2. See Gibney, Tomasěvski, \& Vedsted-Hansen, supra note 1 (one of the few works in this field). 
rights institutions focuses on the national or internal obligations that states have and how states that have ratified the various human rights instruments implement these provisions within their national borders. Although human rights guarantees stem from international treaties and the obligations, therefore, are of an international nature, the subjects of the human rights protection are normally the state's own nationals and residents. International human rights law is part of the general regime of international law in that its sources stem from treaty law, customary international law, and general principles of law. International human rights law, however, is different from other areas of international law because the implementation of the provisions of these treaties, or the norms of customary international law in this field, commonly is done domestically. Thus, there is a vertical relationship between a state and its subjects, rather than a horizontal relationship among states. ${ }^{3}$

Accepting that this is the main thrust of international human rights law obligations, this article will challenge the notion that this is the only sphere in which states have obligations pertaining to this part of international law. In this article, we will address the following questions:

- In which areas do states' trans- or cross-border operations play a role in terms of human rights enjoyment?

- What are the legal foundations for obligations in this field?

- What are the experiences of the international bodies responsible for human rights monitoring and international judicial bodies in dealing with cross-border obligations?

- Are there implications in terms of "obligations of result" and "obligations of conduct"?

- What is the sovereignty paradox that this approach may imply?

3. Allan Rosas holds that "[t]he Universal Declaration offers a paradigmatic challenge to the Hobbesian strand of the Westfalian legacy, which has seen their international system as a horizontal inter-state system based on the sovereign equality of states." This is because the Universal Declaration:

- concerns matters between the state and its own population (vertical approach) other than inter-state relations;

- concerns all human beings, who, in the words of Article 1 of the Declaration, "are born free and equal in dignity and rights," rather than the nationals (citizens) of a given state;

- is a proclamation and interpretation of universal values, rather than a negotiated compromise between the different wills (interests) of states.

Allan Rosas, State Sovereignty and Human Rights: Towards a Global Constitutional Project, XLIII Pol. Stud. 61, 62-63 (footnote omitted) (1995). See also Harry J. Steiner \& Philip Alston, International Human Rights in Context: Law, Politics and Morals 57 ff. $(2 \mathrm{~d}$ ed. 2000). 
This article will only address the effects of states' direct involvement in transnational activities. Although interesting and important, we will not be able to address the extent to which states are under obligations to regulate the transnational conduct of private parties under their jurisdiction (third party regulation). This should not be taken to imply that we regard it as less important, but rather a choice of focus for this article.

\section{TRANSNATIONAL ACTIVITIES}

In these times of globalization, the role of the individual state has changed and, in some measure, diminished. ${ }^{4}$ The role of the state in guiding economic policy, which may enhance or threaten human rights enjoyment, is largely reduced. ${ }^{5}$ International forces increasingly determine national decision making, particularly in smaller states and poorer states, and the power of private international forces, such as transnational corporations (TNCs), often imply that governments' scope of choice is limited. ${ }^{6}$ This reality has not only been recognized by academics but also has been acknowledged by the United Nations. In his study from 1992 on the realization of economic, social, and cultural rights, the UN Special Rapporteur, Danilo Türk argues:

The legal basis upon which economic, social and cultural rights rest, essentially assumes the presence of a "strong" State as the motor behind realizing these rights, combined with a correlative national approach toward this category of legal entitlement. This view, however, is clearly at odds with the prevailing political realities of a majority of States, as well as views of the allegedly "appropriate role" of the State.?

Writing almost ten years later, the UN Secretary General expressed very similar opinions when commenting on the benefits and challenges of globalization:

4. See Sigrun Skogly, Democracy and Human Rights: The Role of the International Donor Community in Africa, 2, 1 J. Third World Spectrum 81 (1995) (discusses the paradox of state human rights obligations in times of globalization).

5. In an article on globalization and human rights, Virginia Leary states, "[u]nder structural adjustment programmes, governments are less able to freely adopt economic and social policies; international financial institutions and transnational corporations are often the real influences in the adoption of such national policies." Virginia Leary, Globalisation and Human Rights in Human Rights: New Dimensions and Challenges 265-266, 281 (Janusz Symonides ed., 1998).

6. See generally Human Rights Standards and the Responsiblitity of Transnational Corporations (Michael K. Addo ed., 1999).

7. Danilo Türk, Special Rapporteur, United Nations, Economic and Social Council, The Realization of Economic, Social and Cultural Rights_Final Report, UN Doc. E/CN.4/ Sub.2/1992/16, 3 July 1992, at 23, II 85. 
Weak states are one of the main impediments to effective governance today, at
national and international levels alike. For the good of their own people and for
the sake of our common aims, we must help to strengthen the capacity of those
states to govern, not undermine them further. . . By the same token, states need
to develop a deeper awareness of their dual role in our global world. In addition
to the separate responsibilities each state bears toward its own society, states
are, collectively, the custodians of our common life on this planet-a life the
citizens of all countries share. Notwithstanding the institutional turmoil that is
often associated with globalisation, there exists no other entity that competes
with or can substitute for the state. Successfully managing globalisation,
therefore, requires-first and foremost-that states act in a manner consistent
with their dual role.

Thus, the crucial role of a strong and organized state is recognized by commentators on globalization and the fulfillment of human rights. Concurrently, it is recognized that the forces of globalization in their present form may reduce the strength of the state. It is also acknowledged that states are involved in more international activities than ever before, not least through their work in intergovernmental organizations and in their attempts to liberalize international trade.

In terms of transnational human rights obligations, all of these activities become important. Human rights are commonly divided into five groups: civil, political, economic, social, and cultural. Although emphasis is constantly placed the interdependence and indivisibility of all categories of human rights (and rightly so), the actual effect of transnational operations by states may be more common and visible in the area of economic and social rights. ${ }^{9}$ This effect may be explained by the nature of states' transnational activities at the beginning of the twenty-first century. States are commonly involved in international security issues, in development assistance, in trade relations, and in work with intergovernmental organizations, all of which promote international economic and social development. Thus, they are involved in activities that influence people's financial and material resources, through employment opportunities (and employment conditions), through the advancement of liberalized trade, agricultural developments and advancement, educational opportunities, and also through arms sales, which can greatly influence the resources available for economic and social development necessary for the improvement in levels of human rights enjoyment.

We are not saying that it is only economic and social rights that require

8. Kofi Annan, The Role of the United Nations in the 21st Century, Report presented by the Secretary-General on 4 Apr. 2000, at 11.

9. This statement needs qualification. In the article by Gibney, Tomasěvski, and VedstedHansen, the authors document serious issues in relationship to civil and political rights as well, not least in terms of granting export licenses to companies producing torture equipment. See Gibney, Tomasěvski, \& Vedsted-Hansen, supra note 1, at 271-72. 
financial resources from the state. To the contrary, such provisions are absolutely necessary to the fulfillment of civil and political rights as well. In a recent report, the International Council on Human Rights Policy documented how important resources are-both domestic (internal) and international (external)—for the establishment and running of an adequate system for the administration of justice. ${ }^{10}$ Nevertheless, the most frequent, and most direct, influence on the enjoyment of human rights by foreign states' activities is most likely to be seen in the area of economic and social rights. Thus, without making any normative judgment as to the relative importance of human rights in general, the main focus of this article will be on economic and social rights.

In order to illustrate where transnational activities may influence human rights, it may be of interest to look at the approaches of two countries. In a recent White Paper, the Norwegian government called for a strengthening of Norway's promotion of internationally recognized human rights beyond its own borders. It stated, "Human rights are for all individuals, whether or not they live in Norway or in other parts of the world. This universality principle gives a moral and legal imperative for all to contribute to a global human rights protection."11 The Norwegian government wants to focus its attention through development cooperation, work through the human rights sections in the United Nations, and in other international human rights organizations. ${ }^{12}$ Differing slightly from this is a Swedish Government White Paper from 1998 in which the approach to human rights in a transnational setting was more extensive. This Swedish White Paper emphasized that an integrated human rights policy shall be an integral part of the entirety of Swedish foreign policy, including development assistance, trade relations, military and security cooperation, voting in intergovernmental organizations, and refugee policy. ${ }^{13}$ Thus, this approach brings human rights to all elements of Swedish foreign policy, while the Norwegian approach limits its foreign policy to only part of its transnational operations. Notwithstanding the differences between these two countries, however, both illustrate that there is now a growing recognition that the promotion of human rights implies more than ensuring that human rights are not violated in each state's domestic setting, but also that activities the state is engaged in abroad may have human rights implications.

10. See International Council on Human Rights Policy, Local Perspectives: Foreign Aid to the Justice Sector, Geneva, International Council on Human Rights Policy, June 2000.

11. Det Norske Storting, St. Meld. Nr. 21 (1999-2000), Menneskereverd $i$ Sentrum (The Norwegian Parliament, White Paper No. 21, 1999-2000 Human Dignity in Focusauthor's translation), Ch. 2, available at <http://odin.dep.no/repub/99-00/stmld/21> [hereinafter: Norwegian White Paper].

12. See id.

13. See The Swedish Government, Human Rights in Swedish Foreign Policy, White Paper 1997/98:89, at 12 (Original Title Regeringens skrivelse 1997/98:89: Mänskliga rättigheter i svensk utrikespolitik, author's translation). 


\section{LEGAL FOUNDATION FOR TRANSNATIONAL HUMAN RIGHTS OBLIGATIONS}

Any discussion of the implementation or the promotion of human rights obligations beyond national borders needs first to establish the legal foundations for these claims. The basis for any such obligation would be found not only in international human rights covenants and conventions but also in the UN Charter. As members of the United Nations, states have pledged themselves to "achieve international cooperation in solving international problems. . . . And in promoting and encouraging respect for human rights and for fundamental freedoms. . .."14 Further, in Article 56, UN members "pledge themselves to take joint and separate action in cooperation with the Organisation for the achievement" of "universal respect for, and observance of, human rights and fundamental freedoms."15 These provisions, seen in conjunction with Article 103, which states that obligations under the Charter will prevail over other obligations in international law, ${ }^{16}$ imply that member-states of the UN will be under an obligation to operate in accordance with respect for human rights. By the very inclusion of human rights in the UN Charter, they became a matter of international concern. ${ }^{17}$

The UN Charter by itself, however, may not be enough to claim that states have legal obligations to ensure that their own transnational activities do not jeopardize human rights in other countries. In fact, whether the wording in Articles 55 and 56 represents a legal obligation upon states to cooperate in the international community to attain the goals of the United Nations has been disputed. ${ }^{18}$ In order to assess the extent to which such legal obligations exist, the provisions of the UN Charter need to be seen in light of the developments in international human rights law in the latter half of the last century.

Compared to the present day, the UN Charter was drafted in an era with strong nation-states, centralized control of power, and limited international interaction. The technological facilities for international interaction were

14. U.N. Charter, art. 1(3), signed 26 June 1945, 59 Stat. 1031, T.S. No. 993, 3 Bevans 1153 (entered into force 24 Oct. 1945).

15. Id. art. 55.

16. Article 103 of the UN Charter reads: "In the event of a conflict between the obligations of the members of the United Nations under the present Charter and their obligations under any other international agreement, their obligations under the present Charter shall prevail." Id.

17. See Hersh Lauterpacht, International Law and Human Rights 146 (1950).

18. See generally Lauterpacht, supra note 17; Egon Schwelb, The Influence of the Universal Declaration on Human Rights on International and National Law, AM. Soc. INT'L L. Proceedings, 1959; The Charter of the United Nations: A Commentary (Bruno Simma ed., 1994); Louis B. Sohn, The Human Rights Law of the Charter 12 TEXAS INT'L L. J. (1977). 
limited to the telephone, and air traffic for business purposes was in its early days. In this situation, national authorities retained a strong hand in the internal development of their respective states through capital control, control over the movement of people, and restrictions on international investment. In the last two decades, marked by the massive opening up of markets and globalization in general, many governments' abilities to control what their own subjects are doing as well as to influence foreign actors, whether natural or legal persons, has been reduced. In this climate, where free market competition has been the guiding principle in the foreign affairs of the dominant states in the international society, it is easy to forget the possible negative human effects of these activities.

To discuss these legal arguments, it is necessary to look at the sources of international law, both in terms of de lege lata and what may be in the process of development. This section will be divided into three separate parts: a) customary international law; b) treaty law; and c) soft law.

\section{A. Customary International Law}

There are many controversial areas of customary international law in regards to human rights that will not be dealt within this article. Due to the recent inclusion of human rights law in international law, it is difficult to use the traditional "test" in determining the existence of customary rules in this field. ${ }^{19}$ Nevertheless, there seems to be a general consensus that at least certain parts of international human rights law have gained status as customary international law, and as such, are binding upon all states. ${ }^{20}$ Some commentators claim that all of the Universal Declaration of Human Rights (Universal Declaration) represents international customary law, ${ }^{21}$ while others take a more cautious attitude and include only a few of the rights or certain elements of the rights contained in the Universal Declaration. ${ }^{22}$ All states are under an obligation to respect the rights that have this status. The question becomes whether this obligation to states is related only

19. It is common to require that a norm fulfill the following criteria in order to be established as customary international law: a consistent state practice for a period of time, followed by an opinio juris. See generally Rosalyn Higgins, Problems and Process: International Law and How We Use it (1993).

20. See Theodor Meron, Human Rights and Humanitarian Norms as Customary law 80 (1989).

21. This view has been advocated by Sohn: "The Declaration, as an authoritative listing of human rights, has become a basic component of international customary law, binding on all states, not only on members of the United Nations." Louis Sohn, The New International Law: Protection of the Rights of Individuals Rather than States 32 Aм. UNIv. L. Rev. 17 (1982), quoted in Meron, supra note 20, at 82.

22. Oscar Schachter, International Human Rights, Hague Academy of Int'L Law, Receulls des COURS, 334-35 (1982). 
to their own population, or whether indeed states have obligations in relationship to the subjects of other states as well.

Due to the relatively restrictive nature of the content of customary international norms in the field of human rights, some commentators imply that these norms carry mainly negative obligations. These commentators argue that states' obligations pertaining to customary international human rights law will be regarded as obligations not to interfere, not to violate-or rather that these obligations will be fulfilled if the state refrains from acting. To illustrate, the prohibition of torture is a recognized rule of customary international law by which states are under an obligation to refrain from torturous practices. The more positive obligations to train police personnel not to carry out torture or to ensure that torture victims receive adequate treatment may not be part of the customary element of this right. Similarly, the right to food and the right to life may have customary international law elements to them in that states are under an obligation not to deliberately starve people by removing their food supply. However, the more positive elements of these rights, such as the obligation to ensure that people have access to food in quantities and qualities that are sufficient for their mental and physical development in a manner that is culturally acceptable, ${ }^{23}$ may not be of a customary nature. Thus, the wider content of these rightsbeyond the customary elements - may be seen to be of a positive nature, and will be of firmer obligations based on treaty law to which only the states that have ratified the treaties can be held accountable.

Thus, in terms of transnational obligations based on customary international law, it would be fair to assume that the content of the obligation would be of a negative nature-states should refrain from actions in their international or transnational operations that will fail to respect the human rights of people in other states. To illustrate, there may be an obligation not to supply a foreign state with torture equipment. There is, however, no obligation to send personnel to train the police in non-torturous practices, although a state could do so legitimately if the foreign state agreed.

As customary human rights law develops, the national boundaries for obligations pertaining to these norms will be weakened. We have seen this weakening in the application of universal jurisdiction for certain violations of human rights, particularly in terms of torture, extrajudicial killings, and crimes against humanity. ${ }^{24}$ It is pertinent to assume that in a globalized

23. See UN Committee on Economic, Social and Cultural Rights, General Comment No. 12, Right to Adequate Food, U.N. Doc. No. E/C.12/1999/5, at II 11.

24. See Regina v. Bartle and the Commissioner of Police for the Metropolis and Others Ex Parte Pinochet (House of Lords Mar. 24, 1999); Filartiga v. Pena-Irala, 630 F.2d 876 (2nd Cir. 1980); Attorney General of Israel v. Eichmann, 36 INT'L. L. Rep. 277 (Sup. Ct. Israel 1962). 
world where individual citizens' lives are heavily influenced by operations by actors beyond one's national borders, the obligation to respect customary international human rights law in transnational operations will be considerably strengthened. It will be increasingly recognized that, not only are there governments that are unwilling to ameliorate the human rights effects of foreign actors within their own borders, but also that they are unable to do so, due to political and economic inequalities, in the international community as well.

In terms of transnational obligations, the principle would be that states would have a duty to act in accordance with customary international human rights law in their international operations to the extent that people in a foreign state do not suffer as a result of the first state's action. In fact, principles of diplomatic protection and state responsibility could be used as an analogy in this setting. It is a recognized principle that states shall refrain from causing harm to another state. ${ }^{25}$ Another principle holds that if a state harms another state's national, this action in international law terms is seen to cause harm to the second state. ${ }^{26}$ If one state harms the national of another state when this national still is in his or her own state, however, the issues of diplomatic protection or state responsibility do not seem to be carried as far. For example, if an agent of a state travels to another state and assassinates one of that state's nationals, quite obviously, a case of responsibility will be triggered. If the first state gives an export licence for torture equipment to be sold to the second state and citizens of the second state die from torture, however, the issue of responsibility is not as clear. ${ }^{27}$

The customary norm is a prohibition of torture, but the implementation of this prohibition so far has been seen to be of a rather strict internal operation (apart from cases such as the Pinochet case, but in that case, it was the prosecution that was abroad, not the effects of the state's actions). ${ }^{28}$ In the torture equipment example, one could easily argue that the importer state is to blame, as it was this state that chose to use the equipment. It is also a valid argument, however, that by making torture equipment available, the first state is at least an accomplice to the crime of torture and should assume part of the responsibility. Similarly, if a state was asked to grant credit guarantees for investment in another state, and this guarantee would

25. See Trail Smelter Case, supra note 1.

26. See Malcolm N. Shaw, International Law 562 (4th ed. 1997).

27. See Gibney, Tomasěvski, \& Vedsted-Hansen, supra note 1, at 271-72.

28. There is now, however, a new take on this case. There is now a possibility that General Pinochet will be indicted in the United States for his involvement in the murder of Orlando Letelier and a colleague in Washington DC in 1976. Letielier was a former Chilean Ambassador to the United States and a prominent opponent of Pinochet. See Fredric L. Kirgis, Possible Indictment of Pinochet in the United States, Am. Soc. InT'L Law INSIGHTS (Mar. 2000), available at <http://www.asil.org/insights.htm>. 
only be granted on the condition that trade unions were outlawed in the industry in which investment was sought, human rights issues would be at play, but rarely invoked. In this scenario, the deliberate act of the creditguaranteeing state would infringe upon the rights of the population in the receiver state.

\section{B. Treaty Law}

In addition to the already mentioned provisions of the UN Charter, there are a number of other treaty provisions that may be of relevance in international human rights law. The most prominent instruments from which transnational human rights obligations may be established are the International Covenant on Economic, Social, and Cultural Rights (ICESCR), ${ }^{29}$ and the International Covenant on Civil and Political Rights (ICCPR). ${ }^{30}$ In respect to transnational obligations, there may be a rather substantive difference between the two Covenants. The general obligation provisions can be found in Article 2 of both Covenants. Article 2 of the ICESCR contains the following passage:

1. Each State Party to the present Covenant undertakes to take steps, individually and through international assistance and co-operation, . . . with a view to achieving progressively the full realisation of the rights recognised in the present Covenant. (Emphasis added.)

Article 2 of the ICCPR is rather different in that it states:

1. Each State Party to the present Covenant undertakes to respect and to ensure to all individuals within its territory and subject to its jurisdiction the rights recognised in the present Covenant. (Emphasis added.)

These texts seem to indicate that the obligations upon the ratifying states are tied more firmly to national borders in terms of civil and political rights than for economic and social rights. Civil and political rights are guaranteed within the ratifying state's territory and for individuals over whom it exercises jurisdiction. On the other hand, economic, social, and cultural rights shall be achieved individually and "through international assistance and cooperation," without specifying a territorial or jurisdictional

29. International Covenant on Economic, Social and Cultural Rights, adopted 16 Dec. 1966, G.A. Res. 2200 (XXI), U.N. GAOR, 21 st Sess., Supp. No. 16, U.N. Doc. A/6316 (1966), 993 U.N.T.S. 3 (entered into force 3 Jan. 1976). Current ratifications: 143 (as of Jan. 2001).

30. International Covenant on Civil and Political Rights, adopted 16 Dec. 1966, G.A. Res. 2200 (XXI), U.N. GAOR, 21 st Sess., Supp. No. 16, U.N. Doc. A/6316 (1966), 999 U.N.T.S. 171 (entered into force 23 Mar. 1976). Current ratifications: 147 (as of Jan. 2001). 
limitation. Without going into detail on the specifics of the various aspects of the obligations as provided by the two Articles 2, it seems that a preliminary conclusion can be drawn that the drafters of the ICESCR have envisioned that the fulfillment of these rights has transnational dimensions as well as domestic ones. ${ }^{31}$

This vision is also evidenced in other articles of the ICESCR, particularly in Article 23, which states, inter alia, that:

The States Parties to the present Covenant agree that international action for the achievement of the rights recognized in the present Covenant includes such methods as the conclusion of conventions, the adoption of recommendations, the furnishing of technical assistance, etc. (Emphasis added.)

This article is seemingly rather weak in the role it envisions for transnational operations, in terms of promoting economic, social, and cultural rights. It is significant in this endeavor, however, that the ICESCR specifically recognizes the role of not only the ratifying state, but also states outside national borders. It should also be noted that the listing of activities that other states are supposed to engage in to achieve the rights listed in the ICESCR are examples and cannot be read as an exhaustive list, as the article itself uses the term "such methods as."

\section{Soft Law}

The final section under the legal basis for obligations concerns "soft law," a term that includes decisions of international bodies and UN organs, such as Convention-based Committees. ${ }^{32}$ In their work on the various human rights conventions and covenants, these Committees have produced authoritative interpretations of the substantive content of rights, as well as the procedural and substantive obligations of the state parties. In this regard, the Committees have assisted in clarifying the understanding of international human rights law within their specific areas of expertise.

31. It should be noted that, although the ICESCR seems clearer in respect to transnational obligations, this should not lead to a conclusion that such obligations only pertain to these specific rights. Clearly, as was discussed in the above section, transnational human rights obligations based on customary law (civil, political, cultural, economic, and social) will be applicable to this comprehensive set of rights.

32. The implementation of the following human rights conventions and covenants are supervised by expert Committees: the ICCPR, the ICESCR, the Convention on the Elimination of All forms of Racial Discrimination, the Convention on the Elimination of Discrimination against Women, the Convention Against Torture and Other Cruel, Inhuman or Degrading Treatment or Punishment, and the Convention on the Rights of the Child. 
In terms of transnational obligations, the Committee of Economic, Social, and Cultural Rights ${ }^{33}$ has issued several interesting statements. For instance, in May 1999, this Committee passed General Comments on The Right to Adequate Food, as recognized in Article 11 of the ICESCR. ${ }^{34}$ In this General Comment, the Committee stated:

States Parties should recognise the essential role of international cooperation and comply with their commitment to take joint and separate action to achieve the full realisation of the right to adequate food. In implementing this commitment, State parties should take steps to respect the enjoyment of the right to food in other countries, to protect that right, to facilitate access to food and to provide the necessary aid when required..$^{35}$

In the most recent General Comment from the same UN Committee, the General Comment on the Right to Health, the statements of transnational obligations seem to be even clearer. The Committee here states:

To comply with their international obligations in relation to article 12, States parties have to respect the enjoyment of the right to health in other countries, and to prevent third parties from violating the right in other countries, if they are able to influence these third parties by way of legal or political means, in accordance with the Charter of the United Nations and applicable international law. Depending on the availability of resources, States should facilitate access to essential health facilities, goods and services in other countries, wherever possible and provide the necessary aid when required. ${ }^{36}$

Compared to some earlier instruments dealing with economic and social rights and the obligations pertaining to them, this is a clear enhancement of international obligations of states. For example, in the Maastricht Guidelines, ${ }^{37}$ adopted by a group of experts in 1997, the section on transnational

33. This is the only treaty-related committee that was not established through the treaty text itself. This committee was established in 1986, based on the model of the already existing expert committees established by the individual conventions.

34. UN Committee On Economic, Social and Cultural Rights, General Comment 12 (UN Doc. E/C.12/1999/5), 12 May 1999.

35. Id. II 36. The legal basis for this statement is referred to in UN Charter, article 56. The specific provisions contained in articles 11, 21, \& 23 of the International Covenant on Economic, Social and Cultural Rights, and the Rome Declaration of the World Food Summit. Id.

36. UN Committee on Economic, Social and Cultural Rights, General Comment No. 14, The Right to Health, U.N. Doc. No. E/C.12/1999/5, at II 39.

37. The Maastricht Guidelines on Violations of Economic, Social and Cultural Rights, adopted by a group of thirty experts in Maastricht, 22-26 Jan. 1997. The objective of this meeting was to "elaborate on the Limburg Principles as regards the nature and scope of violations of economic, social and cultural rights and appropriate responses and remedies." International Commission of Jurists, MaAstricht Guidelines, Introduction 81 (Nov. 1997). (The Limburg Principles on the Implementation of the International Covenant on Economic, Social and Cultural Rights, were adopted by a group of distinguished experts 
obligations is weak because the obligations generally are seen to be of a national character. ${ }^{38}$

However, addressing the role of international financial institutions, the UN Committee on Economic, Social and Cultural Rights, in General Comment no. 2 dealing with structural adjustment programs, held:

[A]djustment programmes endeavours to protect the most basic economic, social and cultural rights become more, rather than less, urgent. States parties to the Covenant, as well as the relevant United Nations agencies, should thus make a particular effort to ensure that such protection is, to the maximum extent possible, built-in to programmes and policies designed to promote adjustment. ${ }^{39}$

On a more general level, the Vienna Declaration and Programme of Action Part I, paragraph 13 confirms that "[t]here is a need for States and international organisations, in cooperation with non-governmental organisations, to create favorable conditions at the national, regional and international levels to ensure the full and effective enjoyment of human rights."

Thus, in customary international law, treaty law, and in a variety of soft law expressions, the role of the state beyond its national borders in protecting human rights is clearly recognized. As a result, it is quite a paradox that so-called international human rights should only have a national dimension.

\section{CASE LAW}

The introduction to this article started by a reference to the Trail Smelter case, in which the state's responsibility for negative effects on another state's territory is quite clearly established. In terms of human rights case law, however, this area continues to evolve, and the international jurisprudence is by no means consistent. It seems that the main issue that the courts or committees have problems with is in determining the direct link between state actions and the resulting human rights violations in other countries. There are, however, some interesting decisions that illustrate the different approaches.

In Loizidou v. Turkey, the European Court of Human Rights stated that

in international law, in Maastricht on 2-6 June, 1986, International Commission of Jurists, LIMBURG Principles 65 (Nov. 1997).

38. The Maastricht Guidelines, supra note 37, II 16 reads "The violations referred to in section II are in principle imputable to the State within whose the jurisdiction they occur. As a consequence, the State responsible must establish mechanisms to correct such violations, including monitoring investigation, prosecution, and remedies for victims."

39. General Comment No. 2 (1990), International Technical Assistance Measures, Covenant, art. 22, supra note $29, \mathrm{E} / 1990 / 23$, at 86-88. 
responsibility for one's own acts can reach outside its jurisdiction. ${ }^{40}$ In this case, which concerned the confiscation of property in the Turkey-occupied areas of Northern Cyprus, the court held that the responsibility of contracting parties can be involved because of acts of their authorities, whether performed within or outside national boundaries, which produce effects outside their own territory. ${ }^{41}$

Similarly, in cases concerning the extradition of people to countries where they may face torture or capital punishment, the European Court of Human Rights has consistently held that this would be a violation of Article 3 of the European Convention for the Protection of Human Rights and Fundamental Freedoms. This was held, inter alia, in Soering v. United Kingdom. ${ }^{42}$ A similar, although more limited, application of this principle has been acknowledged by the UN Human Rights Committee in $\mathrm{Ng} \mathrm{V}$. Canada..$^{43}$ In Ng, the applicant had been extradited from Canada to the United States to stand trial in California where he was likely to face the death penalty by gas asphyxiation. The Committee held that this would be a violation of Article 7 of the ICCPR, as the execution of a capital punishment sentence must be "carried out in such a way as to cause the least possible physical and mental suffering." ${ }^{44}$ Thus, the UN Human Rights Committee held that, even if capital punishment is not prohibited by the ICCPR, the likely punishment that this applicant would face would be in contravention of the ICCPR, and therefore, Canada's extradition was in violation of the ICCPR. ${ }^{45}$

There is also some recognition that states have a responsibility to control criminals and terrorists on their territory who may cause harm in another state. This responsibility has been confirmed in Lawless v. Ireland, ${ }^{46}$ and McCann v. United Kingdom. ${ }^{47}$ In McCann, which dealt with the use of

40. Judgment, Loizidou v. Turkey, Series A. no. 310, at 24, II 62 (ECHR 23 Mar. 1995), available at <http://hudoc.echr.coe.int/Hudoc1doc/HEJUD/sift/505.txt> (visited 29 Apr. 2002).

41. Id.

42. Judgment, Soering v. United Kingdom, Series A. no. 161 (ECHR 7 July 1989), available at <http://hudoc.echr.coe.int/hudoc/>.

43. Complaint No. 469/1991, Human Rights Committee, Views of the Committee, 5 Nov. 1993, UN Doc. A/49/40, Vol. II.

44. Id. II 16.4. It should be noted that the Committee found that this case was in violation of article 7 because the mode with which the person would be subjected to capital punishment would constitute cruel and inhuman treatment. The Committee, however, did not find a violation of article 6 , which guarantees the right to life because "[t]he Committee notes that article 6 , paragraph 1 , must be read together with article 6 , paragraph 2, which does not prohibit the imposition of the death penalty for the most serious crimes." Id. II 15.3.

45. Id. II 17.

46. European Commission on Human Rights, Lawless v. Ireland, Comm. Report 19.12.59, Eur. Court H.R., series B., no. 1, at 237-41.

47. McCann and Others Judgment, 27 Sept. 1995, Series A., no. 324. 
special SAS forces to prevent terrorist attacks in Gibraltar that lead to the death of three people, the court held that the government is "required to have regard to their duty to protect the lives of the people in Gibraltar including their own military personnel." 48

In other cases, however, the problem of demonstrating a close degree of proximity for the violation has been a ground for dismissal. For instance, in Puccini v. Italy, ${ }^{49}$ which dealt with the sale of antipersonnel mines, the European Commission on Human Rights found the case inadmissible. Thus, it can be seen that the scope of states' transnational obligations and responsibility is still an underdeveloped area of international jurisprudence.

\section{IMPLICATIONS OF “OBLIGATIONS OF RESULT" AND "OBLIGATIONS OF CONDUCT"}

One of the questions that remains to be addressed is what kind of obligations may be advanced to states in their transnational operations. It would be neither pertinent, nor practical, to imply that all states are responsible for all human rights enjoyment everywhere. Rather, there has to be a relatively direct link to activities of the state across borders. One distinction of obligations that has gained some acceptance in international human rights law discourse is the distinction between the obligation of conduct and the obligation of result. In the words of the International Law Commission in their Draft Articles on state responsibility, this distinction implies that "[t] here is a breach by a State of an international obligation requiring it to adopt a particular course of conduct when the conduct of that State is not in conformity with that required of it by that obligation." 50 Furthermore, "[t]here is a breach by a State of an international obligation requiring it to achieve, by means of its own choice, a specified result if, by the conduct adopted, the State does not achieve the result required of it by that obligation." ${ }^{15}$ These two definitions of obligation of conduct and obligation of result, respectively, imply that international law accepts that obligations may be fulfilled through a state's behavior and/or the end result of this behavior.

To use an example where both of these obligations are applied, one could again look at the principle that states cannot extradite a person to a

48. Id. II 192.

49. European Commission of Human Rights, Commission's report of 6 Sept. 1994 on the application (no. 20208/92). This decision was later upheld by the Court, see Court decision, 13 Sept. 1995.

50. Y.B. INT'L L. Comm., U.N. Doc. A/CN.4/SER.a/1996 (Draft Article 20 of the International Law Commission Draft Articles on State Responsibility).

51. Id. Draft art. 21. 
country where that individual is likely to face capital punishment. In this example, the obligation of conduct would be the obligation not to extradite (relating to the state's conduct), while the obligation of result would be that no individual under a state's jurisdiction should be subject to torture, even if the torture would be inflicted in a foreign country.

Looking more generally to the transnational obligations, it seems prudent to emphasize both an obligation of conduct, and of result. In other words, what is emphasized is an obligation related to "best practice" as well as the end result of their actions. By emphasizing best practice, there is a realization that there are many variables that influence the human rights enjoyment of people, and it may at times be impossible to demand from foreign states that the results of their actions may never be linked to situations of human rights violations. If states observed an obligation of conduct, to the extent that human rights effects of their transnational activities were in focus, a large number of negative human rights implications would be avoided. However, this does not mean that states should not look to the end result; indeed, the end result would guide the conduct. States should, nevertheless, be "judged" on their conduct rather more carefully than on the end result of transnational operations.

What is the sovereignty paradox that this approach may imply? Finally, we would like to address how these transnational obligations may influence the very fundamental principle in international law of state sovereignty. Possibly the main reason why the developments in this field have been slow is that the sovereignty principle is so strong, and every time international law tries to address issues of a national character the sovereignty threshold has to be overcome. We have seen this in traditional human rights law, and also to a large extent in international environmental law.

However, there is a paradox in the sovereignty argument when facing transnational obligations. Upon the ratification of the UN Charter, human rights became an issue of legitimate international concern-but it was uncertain how far it could penetrate national sovereignty. Through the development in international human rights law in the last fifty years, this has become clearer, and it is constantly developing. It is now quite accepted that gross human rights violations receive widespread international attention and condemnation by the United Nations; economic sanctions and even humanitarian intervention have become increasingly accepted as reactions to severe human rights situations. On another level, interstate complaint procedures are contained in most of the major human rights conventions, and they have been extensively used in the European Convention of human rights system.

Nevertheless, the idea that one state's activities might have some kind of influence on the human rights situation in another state runs directly contrary to the sovereignty issue. The argument that is often advanced is that 
one state cannot dictate how other states use their resources or conduct their international affairs, whether domestic in origin or international. Thus, selling arms to another state that is likely to use such weapons to oppress internal opposition, or shipping anti-personnel mines to a state where their use is much more likely to harm civilian rather than military populations, or investing in industry that is likely to cause health problems or to deprive people of their land and leave them destitute, these issues are rarely (if ever) addressed in terms of human rights. The receiving state takes the view that the consequences of these arms or mines, or indeed the internal effect of the industry, is simply part of the sovereign decisions of the national government, which also means that there is no accountability on part of the state that provides the weaponry or the financial investment. Yet, it seems to be acceptable from a sovereignty perspective to grant development assistance for agricultural production, for example, with the specified condition that the necessary technical equipment is purchased in the assisting state. However, apparently it is contrary to the principle of sovereignty to put in a condition that the agricultural workers should have a right of association, even if the granting state and the recipient state both have ratified human rights conventions guaranteeing the right of association. The reciprocity of international obligations, which is a fundamental principle in international law, does not seem to apply in these cases.

Realistically, the sovereignty principle is a major hurdle to overcome, as sovereignty is fundamental in the international law discourse. It goes to the core of how states interact in terms of international law. No state can dictate to another state how it should behave. International law, apart from certain elements of customary law, is based on consensus and voluntary adherence. This is quite obvious in the discussions and application of obligations erga omnes. It seems to be an accepted element of international law that certain principles are of such fundamental importance that breaches of these are seen as breaches of obligations that run equally to all other states, and every state has the right to help protect the corresponding rights. When a state breaches an obligation erga omnes it injures every state, including those not specifically affected. As a victim of a violation of the international legal order, every state is therefore competent to bring actions against the breaching state. ${ }^{52}$

Nevertheless, even if there is a breach of an obligation erga omnes, there is no duty upon any state to prosecute. The breach of international law is of such severity that any state will have jurisdiction to prosecute, but due to the respect for sovereignty and comity of each and every state, there is no obligation to act. Thus, if a state blatantly violates human rights in another

52. See Meron, supra note 20 . 
state through its transnational operations (it could be military support, direct support for oppressive regimes, etc.) no state-neither the assisting state, the receiver state, or a third state-is obligated (at least in terms of international law as it is presently constituted) to prosecute or otherwise try to remedy the situation. In fact, the paradox becomes that if the state itself is responsible for massive human rights abuses, it is of a concern to the international community. But if human rights problems or neglect is a result of the involvement of foreign states, all of a sudden, the sovereignty argument carries far more weight.

\section{CONCLUSION}

The topic of transnational obligations is not well developed in international human rights law. In fact, it is in its early stages, largely helped by the occurrences of humanitarian intervention in Kosovo, and the attempted prosecution of General Pinochet. Even if the outcomes of these cases may have represented failures in some respects, they both pointed to weaknesses or discrepancies in current international human rights law which urgently need to be addressed. Increased globalization and the tremendous inequality in terms of state power around the world will increase the call for state accountability, not only domestically but also transnationally. So far, the emphasis has very much been on the respect level of obligations, thus looking at states' direct actions which may in fact cause human rights violations, such as torture or executions. But this needs to be expanded to other areas, including the obligation to protect against harmful activities carried out by third parties. This is a field of study that needs far greater attention from academics, practitioners, and by inter- and non-governmental organizations in the years to come. The call for accountability across borders is only going to be stronger as the borders become weaker. 